\title{
Facilities Management Service Delivery in Public and Private High Rise Residential Buildings in Nigeria: A case study of Eko Court Complex and Niger Towers
}

\author{
O. O. Olanrele ${ }^{1}$, A. Ahmed ${ }^{2}$, H. O. Smith ${ }^{3}$ \\ ${ }^{1}$ Department of Estate Management, Faculty of Built Environment, University of Malaya, Kuala \\ Lumpur, 50603, Malaysia \\ ${ }^{2}$ Department of Architecture, Faculty of Built Environment, University of Malaya, Kuala Lumpur, \\ 50603, Malaysia \\ ${ }^{3}$ Head of Practice, HOS Consult (Quantity Surveyors), Fadeyi, Lagos, Nigeria
}

\begin{abstract}
This study assessed and compared the delivery of Facilities Management (FM) services in public and private high rise residential buildings in Lagos, Nigeria. While some facilities or services may not be available in some public estates, the efficiency of the available ones is inadequate in comparison with the adequacy and efficiency of services provided in private estates. The objectives set for the study include identification of services that are provided in the case studies, service delivery method, and an assessment of the residents' satisfaction of the services. This study adopted questionnaire survey for collection of data. 127 questionnaires were distributed to the residents of the case studies and 93 were returned. Three of which were discarded for incompleteness, thus 90 were analysed. The study found that most but not all of the facilities services expected in high rise buildings are available in the case studies and the services are outsourced under a standard Service Level Agreement. The service delivery in private high rise residential building is better than the public residential high rise buildings as revealed by the study. The study recommends improved standardization of services, customized services and meeting customer's expectation for improved service delivery.
\end{abstract}

\section{Introduction}

Residential property refers to the housing /dwelling units for human habitation. Housing is regarded as social goods to be provided by the government and/or its agencies for the citizenry. In the event of the even increasing population and limited land, high rise residential block is being favoured to be able to accommodate a large number of people within a limited land space (unit). In the Western world and developed nation of Asia, majority of the residential units are in multi-storey developments which demand for provision of some facilities and services to make the properties functional, such facilities/services include lift/elevator, adequate power supply, water provision, cleaning, waste disposal, horticulture, security, reception, laundry, recreation etc. These facilities and services need to be efficiently managed and maintained to meet the expectation of the residents. High prices of land in urban centres make high rise residential building inevitable and a more practical proposition from economic point of view [1,2]. Population growth coupled with dwindling land stock make high rise living an alternative. Multi-storey residential apartment is therefore seen as the appropriate decision to 
addressing the high demand for accommodation in the midst of limited supply of land for development. Apartment towers and condominium and are the choice of high income earners today.

High rise residential property has its characteristic of multiple owner/occupier and the involvement of specialist firm (company) for management of the properties and the accompanying facilities and services. The main characteristic of this form of property are individual ownership of a unit, share ownership of common property and membership of a body corporation which is responsible for the management of development [3]. Therefore the management of the high rise residential complexes facilities will require expert knowledge.

\section{Literature Review}

Management and maintenance of high rise complexes gave rise to the issue of facilities management [4]. As a result of the high pressure of needs on the revenue of the public, most public residential estates are not provided with adequate facilities and where they are provided, the facilities are not well managed, the extreme cases is inefficient and ineffective service delivery where facilities management are undertaken. Measurement of service delivery/performance is aimed at establishing the satisfaction of clients or users of a product and services. This is done by comparing the actual perception of the service/product against the expectation of the users. Users' expectations are predictions made by consumers about what a good/service could offer while perception is the actual feelings of product/service by consumers; the degree of discrepancy between consumers' perceptions and expectations dictates the service quality and level of satisfaction of consumers.

\subsection{High Rise Residential Development}

The growth in population and increased urbanization has led to a great increase in demand for housing (residential properties). In the advent of technology and limited supply of land for development, the idea of multi-storey/high rise development evolved to cater for more people. This led to the development of towers and high rise apartments to serve as residential estates. High Rise buildings in addition (and more than other types of residential buildings) require provision of more, adequate and efficient facilities and services to make them liveable and attractive to potential occupiers - the citizenry. In these modern days, high rise residential buildings are for the rich and expatriates, because of the social status of the potential occupiers there must be efficient and effective facilities services management delivery. High rise (tower block, apartment tower) residential apartment is a tall building/structure used as dwelling units. In Nigeria, high rise apartment buildings are not uncommon phenomenon, development of Eric Moore Towers in Surulere and the 1004 Estate in Victoria Island both in Lagos state by the Federal Government of Nigeria dated back to 1970s. Following the development of Eric Moore Tower and 1004 estates were various developments by the Lagos State Development and Property Corporation (LSDPC), a public developer. Among the development by LSDPC is the EKO Court Complex in Victoria Island. In the last two decades, there have been a lot of private high rise buildings in Lagos like Niger Tower, Dangote Apartments etc.

\subsection{Service Delivery in Facilities Management}

Facilities management is a fast growing profession across the world. It is a cost cutting initiatives in the 1970s when outsourcing of services became to be popular [5]. Facilities management encompasses multiple activities under various discipline and combines resources which make facilities management vital to the success of organisations. Facilities management has been defined in past researches $[6,7,8,9,10]$. Facilities management can be summarized to mean creation of an environment that is cohesive to carry out an organisation's primary operations taking an integrated view of the services, infrastructure services and use it to give customer satisfaction and value for money through the support for an enhancement of the core business $[5,11,12,13]$. All the definitions of facilities management relate building to business activities and environment (business/commercial properties) but facilities management is applicable to residential properties too. 
For the study, the above Goyal's opinion of facilities management is adapted and facilities management is refers to as "the practice of managing and maintaining building fabrics and all associated equipment and services including the occupants of buildings, and financial resources to ensure the efficient performance of the property to give value for money". The most essential elements in high rise residential facilities management is the value for money which dictates the performance of building in economic terms and also contributes to the effectiveness of such a housing scheme [1]. Facilities management in high rise building is unique because the facilities are jointly maintained by all residents.

\subsection{Service and Service Quality}

"A service is an activity or series of activities of more or less intangible nature that normally but not necessarily take place in interactions between the customer and services employees and physical resources/goods/systems of the services provider (i.e. designed solutions to customer problems)" [14]. Quality of service is now the cornerstone of competitive strategies for the facilities management providers who are seeking to widen and secure their client [1]. Quality service is related to the customers' need and expectations [15,16,17,18,19] submits that service quality comprises five dimensions which if performed satisfactorily would help reduce the cost for monitoring the performance of service contractors [20]. These five dimensions include Reliability, Responsiveness, Assurance, Empathy and Tangibles.

\subsection{Measurement of Service Quality}

Customer satisfaction or dissatisfaction depends on achieving or not achieving three levels of expectation which are implicit, explicit and talent [14]. Measurement of service quality and/or service delivery provides the basis for answering two fundamental questions:

(a) Is what is being done worth doing?

(b) Has it been done well?

Measuring performance has an important role in measuring past achievements and providing the basis for planning and control decisions [21]. Measurement of service delivery/performance is aimed at establishing the satisfaction of clients or users of a product and services. This is done by comparing the actual perception of the service/product against the expectation of the users. The degree of discrepancy between consumer's perceptions and expectations dictates the service quality and level of satisfaction of consumers/users of the products/services. The service quality (SERVQUAL) model can be adapted for use in measuring the service quality of facilities management services. In Facilities management, customer satisfaction is the key deliverable to success of fulfilling contractual obligation $[22,14]$.

In Malaysia, management corporations were established and saddled with the responsibility of facilities management in high rise residential under the Strata Title Act (STA) of 1985. In the western world, facilities management are contracted out to service providers with a clearly defined Service Level Agreement (SLA). In Nigeria, quality of services is measured mostly by the use of Benchmarking where yardstick are set against which the performance of facilities and the quality of services are measured. Here, the standard already established by a provider or in an estate could be taking as yardstick for any other estate to measure up or surpass. FM services could be in-house or outsourced. The Service Quality instrument has been the predominant method used to measure consumers' perceptions of service quality. It has five generic dimensions or factors, stated as follows:

a. Tangibility - Physical facilities, equipment and appearance of personnel

b. Reliability - Ability to perform the promised service dependably and accurately

c. Responsiveness - Willingness to help customers and provide prompt service

d. Assurance - (including competence, courtesy, credibility and security). Knowledge and courtesy of employees and their ability to inspire trust and confidence

e. Empathy - (including access, communication, understanding the customer) Caring and individualized attention that the firm provides to its customers. 


\section{Methodology}

Collection of data was through the administration of a structured questionnaire, the target respondents are the residents of Eko Court Complex and Niger Tower. A total of 127 questionnaires were served in the two case studies 73 in Eko Court Complex and 54 in Niger Towers. 93 were filled and returned within the period of the survey, 55 from Eko Court Complex (3 discarded for incompleteness) and 38 from Niger Towers living 90 returned questionnaires for analysis. The success level by percentage of the number of retrieved questionnaires is as follows; for Eko Court it is $71.23 \%$ and $70.37 \%$ for Niger Towers. Cumulatively the success level by percentage of retrieved questionnaires for both case studies was $70.87 \%$. This shows a relatively high percentage of retrieved questionnaires. The study adopted combination of descriptive statistics and measure of central tendency for analysis and result presented in tables and figures. For Service Quality measurement, the SERVQUAL model was adopted where expectations and perception are measured and Service Score Gap was calculated.

\section{Service Quality Score (Gap) = Mean value of expectations - Mean value of perceptions}

This study listed the services and some attributes of efficient service delivery and the level of efficiency expected by the residents as well as the perceptions and the degree of goodness derived. The use of 4 point Likert Scale was adopted to rank the efficient level. The highest level takes maximum point in ranking, while the least level was ascribed 1 point.

\section{Result and Discussion}

The study found out that all necessary facilities management services that could make a high rise residential apartment liveable, enjoyable and acceptable to residents were available in the case studies. The services were completely outsourced in Eko Court Complex (a public estate) to two consulting firms, (Fola Oyekan \& Associates for tenancy management and Messrs Almog Engineering Ltd for facilities management). For the Niger Towers (a private estate), part of the facilities management services were outsourced while others that are within the managerial capacity of the developer/owner (UPDC) are provided by the appropriate department of the developer/owner (UPDC). The UPDC is wholly responsible for the sale/lease/tenancy administration and management of the estate.

Table 1: Level of Satisfaction Derived on the Building

\begin{tabular}{|c|c|c|c|c|c|c|}
\hline & & & Eko Court Complex & Nige & vers & \\
\hline $\begin{array}{l}\text { Satisfaction } \\
\text { Level }\end{array}$ & Response (F) & $\begin{array}{c}\text { Ranking } \\
\text { (X) }\end{array}$ & FX & $\begin{array}{l}\text { Response } \\
\text { (F) }\end{array}$ & $\begin{array}{c}\text { Ranking } \\
\text { (X) }\end{array}$ & $\begin{array}{l}\mathrm{F} \\
\mathrm{X}\end{array}$ \\
\hline $\begin{array}{l}\text { Highly } \\
\text { Satisfied }\end{array}$ & 8 & 5 & $\underline{40}$ & 7 & 5 & $\underline{35}$ \\
\hline Satisfied & 37 & 4 & $\underline{148}$ & 24 & 4 & $\underline{96}$ \\
\hline $\begin{array}{c}\text { Fairly } \\
\text { Satisfied }\end{array}$ & 6 & 3 & $\underline{18}$ & 7 & 3 & $\underline{21}$ \\
\hline $\begin{array}{c}\text { Not } \\
\text { Satisfied }\end{array}$ & 0 & 2 & $\underline{0}$ & 0 & 2 & $\underline{0}$ \\
\hline $\begin{array}{c}\text { Highly } \\
\text { Unsatisfied }\end{array}$ & 1 & 1 & $\underline{1}$ & 0 & 1 & $\underline{0}$ \\
\hline T0tal & 52 & & 206 & 38 & & $\begin{array}{c}15 \\
2\end{array}$ \\
\hline Mean & 3.96 & & & 4.0 & & \\
\hline
\end{tabular}

This posits that the owner of a private estate partakes in the facilities management services to ensure efficient service delivery towards achieving the aim of profit and business sustenance. The only outsourced facilities are the ones that require core competence of relevant professionals for 
example swimming pools, sewage treatment, lift management and internet/DSTV system. A Service Level Agreement (SLA) which contains the conventional terms exists in case of outsourced services in the case studies. The terms include but not limited to the service, extent, period, mode of delivery, payment and mode of payment, frequency etc)

From the above Table 1, the residents of Niger Towers derived slightly and insignificant more level of satisfaction than resident of Eko Court as reflected in the mean values (Niger Tower 4.0 and Eko Court 3.96). One can deduce that there is no difference between the satisfactions derived from both estates in terms of facilities management services. However, they are not highly satisfied, there is room for improved service delivery from the providers.

Table 2: Level of Satisfaction of each Service as Provided

\begin{tabular}{ccc}
\hline \multirow{2}{*}{ Services } & \multicolumn{2}{c}{ Weighted Satisfaction Level } \\
\cline { 2 - 3 } & Eko Court Complex & Niger Towers \\
\hline Water & 3.96 & 4.58 \\
Electricity & 3.19 & 3.82 \\
Lift & 3.77 & 4.58 \\
Cleaning And Pest Control & 3.85 & 4.63 \\
Refuse Disposal & 3.83 & 3.84 \\
Security & 3.96 & 3.53 \\
General Repairs & 3.79 & 3.52 \\
Aggregate Mean & 3.76 & 4.07 \\
\hline
\end{tabular}

Source: Author's field survey, July 2011

Niger Towers residents were more satisfied with 5 (water, electricity, lift, cleaning/pest control and refuse disposal) out of the 7 services listed as reflected by the mean values. Eko Court residents are more satisfied with respect to security and general repairs (Table 2). The distribution is not unexpected, more foreigners reside in Eko Court and the security is expected to be good. Also Eko Court Complex was built three decades ago and has experience renovations/repairs as against the Niger Towers that was built about seven years ago and which has never experience any major renovation/repair work. This gives the Eko Court resident more ability to express service delivery with regard to general repairs than the resident of Niger Towers. On the aggregate, Niger Towers are better satisfied (see Figures $1 \& 2$ also).

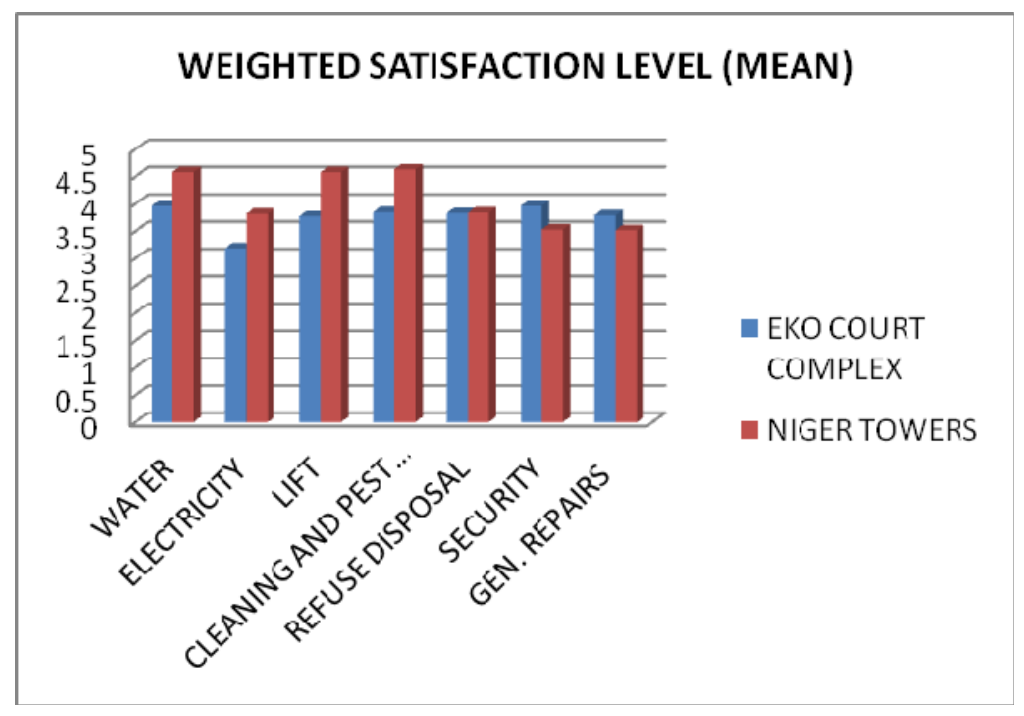

Figure 1: 3D chart view of weighted satisfaction level of each service for both estates 
In the context of the facilities management service delivery, 20 indicators of both services and attributes of service delivery (Table 4) measure the performance using a four (4) point Likert Scale measuring both customer expectations and perceptions. The satisfaction level of each service provided in the case studies further confirmed that the service delivery in Niger Towers is better than in Eko Court as revealed in Table 3 above. The mean values in five out of the seven variables are higher in Niger Towers than Eko Court. The aggregate mean value in Niger Towers is 4.07 against 3.76 in Eko Court. The Figure 1 below show the 3 dimensional chart view of the above Table 2 .

Table 3: Satisfaction in Respect to General State of Repairs of the Estates

\begin{tabular}{ccccccc}
\hline \multirow{2}{*}{ Satisfaction Level } & \multicolumn{2}{c}{ EKO COURT COMPLEX } & \multicolumn{4}{c}{ NIGER TOWERS } \\
& Response (F) & Ranking (X) & FX & Response (F) & Ranking (X) & FX \\
\hline Highly Satisfied & 6 & 5 & $\underline{30}$ & 18 & 5 & $\underline{90}$ \\
Satisfied & 31 & 4 & $\underline{124}$ & 14 & 4 & $\underline{56}$ \\
Fairly Satisfied & 15 & 3 & $\underline{45}$ & 6 & 3 & $\underline{18}$ \\
Highly Unsatisfied & 0 & 1 & $\underline{0}$ & 0 & 1 & $\underline{0}$ \\
T0tal & 52 & & 199 & 38 & & 164 \\
Mean & $\underline{3.83}$ & & & $\underline{4.31}$ & & \\
\hline
\end{tabular}

Source: Author's field survey, July 2011

With a mean value of 4.31 , the residents of Niger Towers are much more satisfied with general state of repairs of the estate than the resident of Eko Court that has a mean value of 3.83. The percentage distribution of the level of satisfaction to the general state of repairs of the estates is presented in Figure 2.

\section{$\%$ Distribution of level of satisfaction of state of repairs}

\section{\#EKO COURT COMPLEX $\quad$ NIGER TOWERS}
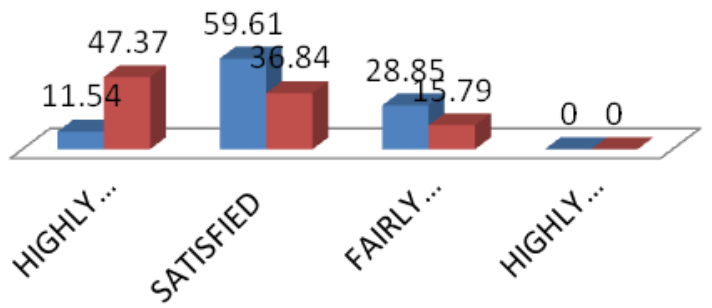

Figure 2: Distribution of level of satisfaction of state of repairs 
Table 4: Service Quality Score (Gap)

\begin{tabular}{|c|c|c|c|c|c|c|c|c|c|}
\hline \multirow[b]{2}{*}{ SERVICE/ATTRIBUTES } & \multicolumn{2}{|c|}{ EKO COURT } & \multirow[b]{2}{*}{ GAP } & \multicolumn{3}{|c|}{ Niger Towers } & \multirow[b]{2}{*}{ MEAN - (P) } & \multirow[b]{2}{*}{ GAP } & \multirow[b]{2}{*}{ RANK } \\
\hline & MEAN -(E) & MEAN - (P) & & RANK & Service/Attributes & MEAN -(E) & & & \\
\hline Waste Discharge & 3.31 & 3.02 & 0.29 & 1 & Accountability & 3.39 & 3.18 & 0.21 & 1 \\
\hline Documentation & 3.21 & 2.88 & 0.33 & 2 & Transparency & 3.39 & 3.11 & 0.28 & 2 \\
\hline Reception & 3.4 & 3.06 & 0.34 & 3 & Lift & 3.45 & 3.13 & 0.32 & 3 \\
\hline Electricity & 3.38 & 2.98 & 0.4 & 4 & Cleaning & 3.61 & 3.24 & 0.37 & 4 \\
\hline Security & 3.56 & 3.15 & 0.41 & 5 & Water & 3.63 & 3.24 & 0.39 & 5 \\
\hline Lightening & 3.37 & 2.96 & 0.41 & 6 & Resident Satisfaction & 3.45 & 3.05 & 0.4 & 6 \\
\hline Resident Database & 3.35 & 2.94 & 0.41 & 7 & Security & 3.32 & 2.89 & 0.43 & 7 \\
\hline Cleaning & 3.35 & 2.92 & 0.43 & 8 & General Repairs & 3.66 & 3.21 & 0.45 & 8 \\
\hline Resident Privacy & 3.83 & 3.4 & 0.43 & 9 & Technicality & 3.37 & 2.92 & 0.45 & 9 \\
\hline Lift & 3.4 & 2.96 & 0.44 & 10 & Electricity & 3.45 & 2.97 & 0.48 & 10 \\
\hline Prompt Response & 3.37 & 2.9 & 0.47 & 11 & Reception & 3.71 & 3.18 & 0.53 & 11 \\
\hline Accountability & 3.56 & 3.06 & 0.5 & 12 & Prompt Response & 3.47 & 2.92 & 0.55 & 12 \\
\hline Resident Satisfaction & 3.4 & 2.9 & 0.5 & 13 & Waste Discharge & 3.61 & 3.05 & 0.56 & 13 \\
\hline Water & 3.31 & 2.75 & 0.56 & 14 & 24 Hrs Service & 3.61 & 3.03 & 0.58 & 14 \\
\hline General Repairs & 3.48 & 2.92 & 0.56 & 15 & Value For Money & 3.58 & 2.97 & 0.61 & 15 \\
\hline Refuse Discharge & 3.42 & 2.85 & 0.57 & 16 & Resident Privacy & 3.66 & 3.05 & 0.61 & 16 \\
\hline Value For Money & 3.44 & 2.84 & 0.6 & 17 & Documentation & 3.74 & 3.03 & 0.71 & 17 \\
\hline Transparency & 3.73 & 3.08 & 0.65 & 18 & Refuse Discharge & 3.34 & 2.61 & 0.73 & 18 \\
\hline 24 Hrs Service & 3.67 & 2.98 & 0.69 & 19 & Lightening & 3.55 & 2.79 & 0.76 & 19 \\
\hline Technicality & 3.52 & 2.82 & 0.7 & 20 & Resident Database & 3.66 & 2.68 & 0.98 & 20 \\
\hline Aggregate Mean & 3.453 & 2.9685 & 0.48 & & & 3.5325 & 3.0125 & 0.52 & \\
\hline
\end{tabular}

Source: Author's field survey, July 2011

The gap in above Table 4 varies in respect of each attribute and service. The highest value of Gap Score in Eko Court is 0.7 while that of Niger Towers is 0.98 out of the highest point of 4 . It is found that in both estates all service delivery rank above $75 \%$ of maximum expected delivery level. The Gap (Service Quality Score) was ranked to identify which of the service does not go near the expectation of the residents and require improved service delivery in each of the estates. Items that ranked 12 to 20 in case of Eko Court will require more attention while on Niger Towers it is items numbered 11 to 20. This is deduced by taking services that has Gap value of 0.5 and above. It is however noticeable that different services/attributes are affected in the estates. There is need for the service providers to improve in such areas to be able to meet the clients' satisfactory level/requirements. Expectation is higher in Niger towers (that is, residents of Niger Towers have higher level of expectation in service delivery). This is attributed to the established standard of similar facility provision by UPDC. The overall analysis shows that the service provision is satisfactory.

For the goodness-of-fit test for this distribution, the critical value of Chi at $95 \%$ confidence level (0.05) in the Chi - square table is 54.57. The calculated Chi square value is 3.12 . The test statistic therefore falls within the non critical region. This affirmed that Facilities management service delivery in public residential estate is not better than that of private residential estates.

\section{Recommendation}

The findings from this research provide a number of managerial implications as well as a variety of directions for the future research. On the basis of the findings of the study, the following are recommended for quality service delivery.

\subsection{Improve Standardization of Services}

The diversity of services increased the difficulty of management control of the human factor in the service quality, which requires that the level of service standard is raised. It is hereby recommended that irrespective of the beneficiaries of facilities management services (public/private), standard quality services should be expected at all time. 


\subsection{Customized Services}

Another important measure to improve the service quality is customized service. Companies must provide the customized service to their customers in order to improve customers' perception of service quality. Customization here means tailoring the service and service quality towards the need and expectation of the users - residents.

\subsection{Feedback}

The facilities management services providers should always get feedback from the users to ensure improvement in service delivery that will improve the clients' satisfaction.

\subsection{Service Recovery}

When system failure occurs, the prompt response to restore same usually leads to higher degree of satisfaction. Service providers should strive to provide customers with "zero defects" service.

\subsection{Infrastructural Facilities}

The government and all concerned public Agencies in Nigeria should deliver public infrastructures that will enhance livelihood like stable electricity, fuel, road network and security among others. A situation where a standby power generating set is devoted to power lift in high rise building with only six hours electricity supply to the residents (with constant public power outages) is not acceptable. For every tower apartment in Nigeria, the technology of solar panel installation and green building should be incorporated in the current wave of sustainability.

\section{Conclusion}

Clearly, the measurement of service quality in the facilities management services should take into account customer expectations of service as well as their perceptions of service. This agrees with Fatoye and Odusami (2) that to different criterion is attached different level of satisfaction by occupiers of residential houses. Therefore the customers expectation of each criterion or indicator of satisfaction be identified and facility managers are to strive to meet such expectation. By addressing the important questions, the facilities management company can understand what service areas it should concentrate on to improve its service quality and customer satisfaction effectively, while avoiding the investment of fund in providing service quality dimensions that may not pay off. Improving dissatisfying factors should generally be a high priority for the facilities management company to pay most attention, and have to implement the service recovery to reduce the customers' feeling of service dissatisfied.

\section{References}

1. Mohd-Tawil, N., Che-Ani, A. I., Sairi, A., Abdulahi, N. A. G., Tahir, M. M., \& Sutar, M. (2010). Facilities Management Indicators for High Rise Residential Property in Malaysia. WSEAS Transactions on Environment and Development, 6(4), 255-264.

2. Jamila, H. (1994). Strata Title in Malaysia. Selangor: Pelanduk Publications (M) Sdn. Bhd.

3. Christudason, A. (2004). Common Property in Strata Titled Development in Singapore. Journal of property Management, 22(1), 14-28.

4. Linariza, H., \& Ashok, V. (2003). Facilities Management: An Introduction. Journal of the Malaysian Surveyor, 38(1), 13-19. 
5. Noor, N. M., \& Pitt, M. (2009). A Critical Review of Innovation in Facilities Management Service Delivery. Facilities, 27(5/6), 221-228.

6. Barrett, P. (1995). Facilities Management Quality System. An Important Improvement Area. Building Research and Information, 23(3), 167-174.

7. Becker, F. (1990). The Total Workplace. New York: Van Nostrand Reinhold.

8. Nutt, B. (1999). Linking FM Practice and Research. Facilities, 17(1/2), 11-17.

9. Tay, L., \& Ooi, J. T. L. (2001). Facilities Management "A Jack of all Trades". Facilities, 19(10), 357-362.

10. Then, D. S. S. (1999). An Integrated Resource Management View of Facilities Management. Facilities, 17(12/13), 462-469.

11. Alexander, K. (1999). Facilities Management. London: E\&FN, Spon.

12. Bell, J. (1990). Facilities Management and Changing Professional Boundaries. Facilities, 10(10), 161-173.

13. Goyal, S., \& Pitt, M. (2007). Determining the Role of Innovation Management in Facilities Management. Journal of Facilities Management, 25(1/2), 48-60.

14. Wei, Z. (2007). Service Quality by a facilities management company in Dragon Lake Residential Community. (M. Sc), Universiti Teknologi, Malaysia.

15. Johnston, R., \& Clark, G. (2005). Service operations management: Improving service delivery:: Prentice Hall.

16. Kotler, P. (2003). Marketing Management: Prentice Hall.

17. Parasuraman, A., Zeithaml, V. A., \& Berry, L. L. (1985). A conceptual model of service quality and its implication. Journal of Marketing, 49, 41-50.

18. Parasuraman, A., Zeithaml, V. A., \& Berry, L. L. (1988). SERVQUAL: A Multi-Item Scale for Measuring Consumers Perceptions of the Service Quality. Journal of Retailing, 64(1), 12-40.

19. Parasuraman, A., Zeithaml, V. A., \& Berry, L. L. (1990). Delivering quality service: balancing customer perceptions and expectations. New York: The Free Press.

20. Lai, J. H. K. (2010). Investigating the Quality of FM services in Residential Buildings. Facilities management and maintenance. Paper presented at the CIB World Building Congress, Salford, United Kingdom.

21. Cole, R. J. (2000). Building environmental assessment methods: assessing construction practices. Construction Management and Economics, 18, 949-957.

22. Siu, G. K. M., Bridge, A., \& Skitmore, M. (2001). Assessing the service quality of building maintenance providers; Mechanical and Engineering services. Construction Management and Economics, 19, 719-726. 